\title{
FAKTOR-FAKTOR YANG MEMPENGARUHI PERMINTAAN DAN PERILAKU KONSUMEN RUMAH TANGGA TERHADAP DAGING SAPI DI KABUPATEN JEMBER
}

\author{
Septian Maulana Purnama ${ }^{1}$, Rudi Wibowo ${ }^{2}$, Ati Kusmiati ${ }^{2}$ \\ ${ }^{1}$ Alumnus, Program Studi Agribisnis Fakultas Pertanian Universitas Jember \\ ${ }^{2}$ Staf Pengajar, Program Studi Agribisnis Fakultas Pertanian Universitas Jember \\ email: seysha_maulana@yahoo.com
}

\begin{abstract}
Beef is one of the food requirements strategically in Indonesia. Consumption of beef each year has increased, while the price of beef also increased, it is contrary to the demand theory. The purpose of this research to know (1) what factors that influence the beef demand in Jember Regency; (2) what factors that influence the behavor of household consumer to consume in Jember Regency (3) preference of household consumer behavior for beef in Jember Regency The research method uses descriptive method and analytic method. The Data analysis use Multiple Linear Regression Analysis, Factor Analysis and Fishbein Multiatribut Analysis. Results from this study indicate (1) the factors affecting demand, namely, income level, chicken meat prices, and population (2) factors that influence the behavior of household consumers to consume in Jember: cultural factor, external character factors of consumers, social factors, the perception factor, privacy factor and motivation factors (3) Household consumer preferences for beef of three variables alternately; piece of meat, meat color and fat content.
\end{abstract}

Keywords: Beef, Preferences, Demand, Consumer Behaviour

\section{PENDAHULUAN}

Pangan merupakan kebutuhan manusia yang paling mendasar karena mengandung zat-zat yang diperlukan untuk pertumbuhan dan perkembangan tubuh serta melakukan berbagai aktivitas. Pangan memiliki peran dalam upaya peningkatan kualitas gizi sumber daya manusia, sehingga upaya perbaikan gizi telah ditetapkan sebagai salah satu bidang yang harus diperhatikan.

Salah satu kebutuhan pangan yang mampu menunjang gizi yaitu daging sapi. Sapi merupakan penghasil daging utama di Indonesia. Konsumsi daging sapi mencapai 19 persen dari jumlah konsumsi daging Nasional (Dirjen Peternakan, 2009).

Kabupaten Jember merupakan salah satu sentra peternakan sapi di Jawa Timur. Produksi daging sapi di Kabupaten Jember terus mengalami peningkatan dari tahun ke tahun.Berdasarkan teori permintaan yang menunjukkan apabila semakin tinggi harga, maka permintaan akan barang tersebut semakin berkurang, tetapi yang terjadi saat ini di Kabupaten Jember berbanding negatif dengan teori. Permintaan terhadap daging sapi semakin meningkat meskipun harga daging sapi yang juga semakin meningkat. Selain itu Konsumen yang mengkonsumsi daging sapi terdiri atas berbagai macam konsumen, salah satunya yaitu konsumen rumah tangga yang pada umumnya lebih sering mengkonsumsi daging sapi untuk kebutuhan tubuhnya. Faktor-faktor yang mempengaruhi perilaku konsumen tersebut juga berhubungan dengan kondisi barang yang akan dikonsumsi. Pemilihan barang berdasarkan atribut barang yang diinginkan oleh konsumen. Adapun tujuan penelitian ini adalah untuk mengetahui : (1) faktor-faktor apa saja yang mempengaruhi permintaan daging sapi; (2) faktor-faktor apa saja yang mempengaruhi perilaku konsumen rumah tangga untuk mengkonsumsi daging sapi; (3) preferensi konsumen rumah tangga terhadap daging sapi yang akan dikonsumsi, khususnya di Kabupaten Jember. 


\section{METODE PENELITIAN}

Tempat penelitian ditentukan secara sengaja (purposive method), yaitu di Kabupaten Jember. Penelitian dilakukan pada beberapa perumahan, beberapa pedagang daging sapi dan beberapa konsumen yang ada di kawasan pasar di Kabupaten Jember. Pasar Tanjung mewakili pasar induk, Pasar Mangli mewakili pasar kota, dan Pasar Mayang mewakili pasar desa.

Metode penelitian yang digunakan dalam penelitian ini adalah metode deskriptif dan metode analitik. Metode deskriptif bertujuan membuat deskripsi atau gambaran mengenai fakta-fakta, sifat-sifat serta hubungan dari fenomena yang diselidiki pada suatu populasi atau daerah tertentu secara sistematis, faktual, dan akurat.

Metode pengambilan contoh yang digunakan adalah Convinience Sampling. Wibisono (2003) mendefinisikan dalam teknik ini, yang diambil sebagai anggota sampel adalah konsumen yang mudah ditemui atau yang berada pada waktu yang tepat, mudah ditemui dan dijangkau.

Pengambilan sampel untuk mengetahui perilaku konsumen dengan menggunakan formulasi:

Dimana :

$$
\mathbf{n}=\mathbf{5 K}
$$

$\mathrm{n}=$ jumlah sampel

$\mathrm{K}=$ variabel

Adapun beberapa kriteria untuk responden agar data yang didapat lebih akurat, kriteria-kriteria tersebut yaitu :

1. Responden sedang membeli atau pernah melakukan pembelian daging sapi.

2. Responden melakukan pembelian untuk konsumsi pribadi atau keluarga, tidak untuk dijual lagi.

Metode pengumpulan data yang digunakan dalam penelitian ini adalah menggunakan wawancara terstruktur (data primer), studi pustaka (data sekunder), dan observasi.

1. Wawancara terstruktur dilakukan dengan menggunakan kuisioner pada konsumen yang akan dijadikan sampel penelitian. Wawancara terstruktur susunan pertanyaannya sudah ditetapkan sebelumnya (biasanya tertulis) dengan pilihan jawaban yang juga sudah tersedia

2. Studi pustaka yaitu dilakukan dengan memperoleh data dari instansi terkait maupun buku-buku dan penelitian yang telah dilakukan sebelumnya. Studi pustaka termasuk pada data sekunder. Data sekunder merupakan data merupakan data yang sudah dalam bentuk dokumen-dokumen

3. Observasi merupakan teknik pengumpulan data yang dilakukan melalui suatu pengamatan seperti mengetahui kondisi daging sapi dan kebutuhan konsumen dalam membeli daging sapi, dengan disertai pencatatan terhadap keadaan atau perilaku obyek sasaran.

Untuk mencapai tujuan pertama mengenai faktor-faktor yang mempengaruhi permintaan daging sapi dianalisis dengan regresi linier berganda. Bentuk umum persamaan regresi linier berganda dapat dituliskan sebagai berikut (Hasan, 2005):

$\mathrm{Y}=\mathrm{a}+\mathrm{b}_{1} \mathrm{X}_{1}+\mathrm{b}_{2} \mathrm{X}_{2}+\mathrm{b}_{3} \mathrm{X}_{3}+\ldots+\mathrm{e}$

Dimana :

$\mathrm{Y} \quad=$ variabel terikat (nilai duga $\mathrm{Y}$ )

$\mathrm{a}, \mathrm{b}_{1}, \mathrm{~b}_{2}, \mathrm{~b}_{3}, \ldots, \mathrm{b}_{\mathrm{k}}=$ koefisien regresi

$\mathrm{X}_{1}, \mathrm{X}_{2}, \mathrm{X}_{3}, \ldots, \mathrm{X}_{\mathrm{k}}=$ variabel bebas

Persamaan permintaan daging sapi yang digunakan adalah sebagai berikut:

$Y=a+b_{1} X_{1}+b_{2} X_{2}+b_{3} X_{3}+b_{4} X_{4}+b_{5} X_{5}+$ $\mathrm{b}_{6} \mathrm{X}_{6}$

Dimana :

Y = konsumsi daging sapi ( $\mathrm{kg} /$ tahun)

$\mathrm{a}_{\text {dan }} \mathrm{b}_{\mathrm{i}}=$ koefisien regresi

$\mathrm{X}_{1}=$ tingkat pendapatan (ribu Rupiah/ kapita/ tahun)

$\mathrm{X}_{2}=$ harga daging sapi (ribu Rupiah/kg/ tahun)

$\mathrm{X}_{3} \quad=$ harga daging ayam (ribu Rupiah/kg/ tahun)

$\mathrm{X}_{4} \quad=$ Jumlah Penduduk (Jiwa/ tahun)

$\mathrm{X}_{5} \quad=$ produksi daging sapi ( $\left.\mathrm{kg} / \mathrm{tahun}\right)$

$\mathrm{X}_{6} \quad=$ populasi sapi (ekor/tahun)

Uji persamaan uji $\mathrm{F}$ digunakan untuk menguji pengaruh seluruh variabel independen terhadap variabel dependen. 
Rumus yang digunakan untuk mencari nilai F hitung adalah

$$
\text { F hitung }=\frac{\text { kuadrat tengah regresi }}{\text { kuadrat tengah sisa }}
$$

Kriteria pengambilan keputusan:

$\mathrm{F}$ hit $>\mathrm{F}$ tabel $(\alpha=0,05)$ maka $\mathrm{H}_{1}$ diterima, berarti variabel independen secara bersamasama berpengaruh nyata terhadap variabel dependen (tingkat konsumsi daging sapi).

$\mathrm{F}$ hit $\leq \mathrm{F}$ tabel $(\alpha=0,05)$ maka $\mathrm{H}_{011}$ ditolak, berarti variabel independen secara bersamasama tidak berpengaruh nyata terhadap variabel dependen (tingkat konsumsi daging sapi).

Uji t digunakan untuk mengetahui pengaruh variabel-variabel independen secara parsial terhadap variabel dependen rumus yang digunakan adalah

$$
\mathrm{t} \text { hit }=\left|\frac{\mathrm{b}_{\mathrm{i}}}{\mathrm{Sb}_{\mathrm{i}}}\right|
$$

Keterangan:

$$
\text { bi }=\text { Koefisien regresi ke-i }
$$

Kriteria pengambilan keputusan:

$\mathrm{t}$ hit $>\mathrm{t}$ tabel $(\alpha=0,05)$ maka $\mathrm{H}_{1}$ diterima, berarti variabel independen ke-i berpengaruh nyata terhadap variabel dependen (konsumsi daging sapi), sedangkan variabel independen lain dianggap konstan.

$\mathrm{t}$ hit $\leq \mathrm{t}$ tabel $(\alpha=0,05)$ maka $\mathrm{H}_{1}$ ditolak, berarti variabel independen ke-i berpengaruh tidak nyata terhadap variabel dependen (konsumsi daging sapi), sedangkan variabel independen lain dianggap konstan.

Untuk menguji seberapa jauh variabel Y yang disebabkan oleh variasi variabel $\mathrm{X}$, menggunakan rumus:

$$
\text { Adjusted } \mathrm{R}^{2}=\mathrm{R}^{2}\left[\frac{(\mathrm{n}-1)}{(\mathrm{n}-\mathrm{k}-1)}\right]
$$

\section{Uji Asumsi Klasik}

Uji ekonometrika dikenal dengan uji asumsi klasik. Uji asumsi klasik untuk mengetahui apakah penggunaan model regresi linier dalam menganalisis data yang telah memenuhi persyaratan asumsi klasik dan menghasilkan nilai estimasi yang Best Linier Unbiased Estimator (BLUE). Asumsi klasik yang harus dipenuhi, antara lain data harus normal, non multikolinier, non autokorelasi dan homoskedastisitas.
Untuk mencapai tujuan kedua, yaitu dengan menggunakan analisis faktor. Analisis faktor merupakan salah satu metode yang digunakan pada statistik multivariate. Tujuan utamanya adalah data reduction dan summarization (Hair et al, 1992). Analisis faktor pada prinsipnya digunakan untuk mereduksi data, yaitu proses untuk meringkas sejumlah variabel menjadi lebih sedikit dan menamakannya sebagai faktor (Santoso dan Fandy, 2004).

Terdapat 3 tahapan dalam analisis faktor untuk mengetahui faktor-faktor yang mempengaruhi perilaku konsumen daging sapi, tahapan tersebut yaitu:

1. Pengujian standar deviasi

2. Uji KMO (Kaiser-Meyer-Olki) and Bartlett's Test

3. Uji MSA (Measurement of Sampling Adequency)

4. Ekstraksi variabel menggunakan Metode PCA (Principal Component Analyze)

5. Analisis Faktor

Nilai KMO (Kaiser-Meyer-Olki) and Bartlett's Test dapat dilihat dengan menyususn hipotesis sebagai berikut:

- $\mathrm{H}_{0}=$ sampel (atribut variabel) belum layak ntuk dianalisis lebih lanjut

- $\mathrm{H}_{1}=$ sampel (atribut variabel) layak untuk dianalisis lebih lanjut

Kriteria dalam melihat nilai probabilitas (tingkat signifikansi):

- Angka Sig < 0,005 maka $\mathrm{H}_{0}$ diterima

- Angka Sig $\geq 0,05$ maka $\mathrm{H}_{0}$ ditolak

MSA digunakan untuk menguji dan mengukur hubungan antar semua indikator yang digunakan. Angka MSA (Measurement of Sampling Adequency) berkisar antara 0 hingga 1, dengan kriteria:

- MSA $\geq 0,5$ sampai dengan 1, atribut variabel dapat diprediksi tanpa kesalahan oleh variabel lain dan dapat dianalisis lebih lanjut

- MSA < 0,5, atribut variabel tidak dapat diprediksi dan tidak dapat dianalisis lebih lanjut.

Analisis faktor digunakan untuk mengukur persepsi responden terhadap variabel atribut yang telah ditentukan. Setiap variabel atribut akan diberi nilai 1 (sangat tidak setuju) sampai 5 (sangat setuju) dalam 
skala tingkatan point (itemized roating scale) dalam bentuk skala likert, yaitu :

1. Sangat tidak setuju

2. Tidak setuju

3. Netral

4. Setuju

5. Sangat setuju

Analisis Multiatribut Fishbein

Untuk mencapai tujuan ketiga yaitu menggunakan analisis multiatribut fishbein. Sebelum menentukan atribut daging sapi, dilakukan observasi terhadap konsumen daging sapi. Kemudian atribut yang dianggap penting oleh konsumen digunakan sebagai acuan dalam pengumpulan data dengan metode wawancara. Analisis multiatribut fishbein digunakan untuk mengetahui atribut daging sapi yang paling dipertimbangkan oleh konsumen ketika mengkonsumsi daging sapi.

Menentukan penilaian kepercayaan terhadap atribut daging sapi (bi) dengan cara menentukan standar penilaian (scoring) dengan menggunakan skala likert, Menurut Sugiyono (2013), Skala likert digunakan untuk mengukur sikap, pendapat, dan persepsi seseorang atau sekelompok orang tentang fenomena sosial. Adapun penilaian secara skala Likert yaitu:

5 sangat baik

4 baik

3 cukup

2 tidak baik

1 sangat tidak baik

Menentukan sikap terhadap obyek $\mathrm{A}_{0}$ dengan rumus dibawah ini:

$$
\text { Ao }=\text { bi . ei }
$$

Keterangan :

Ao : sikap konsumen terhadap daging sapi di Kabupaten Jember

$\mathrm{Bi}$ : tingkat kepercayaan konsumen bahwa daging sapi yang dibeli di Kabupaten Jember memiliki atribut tertentu (variabel ke-i).

ei : dimensi evaluatif (evaluasi) konsumen terhadap atribut ke-i yang dimiliki daging sapi di Kabupaten Jember.

Adapun atribut daging sapi yang diamati berdasarkan hasil observasi yang dilakukan ke beberapa konsumen rumah tangga di Kabupaten Jember:
1. Warna daging sapi

2. Kandungan lemak

3. Bagian daging sapi

\section{PEMBAHASAN \\ Faktor-Faktor yang Mempengaruhi Permintaan Daging Sapi di Kabupaten Jember}

\section{Uji Asumsi Klasik}

Pengujian asumsi klasik ini bermaksud untuk memastikan bahwa model yang diperoleh benar-benar memenuhi asumsi dasar dalam analisis regresi yaitu Best Linier Unbiased Estimator (BLUE).

a. Uji Normalitas

Normalitas data diuji dengan menggunakan uji Kolmogorov-Smirnov dengan level of significant 5\%. Pengujian dilaksanakan terhadap unstandardized residual. Hasil uji normalitas KolmogorovSmirnov disajikan pada Tabel 1.

Tabel 1. Hasil Uji Normalitas

\begin{tabular}{ccc}
\hline Variabel & $\begin{array}{c}\text { Nilai Z } \\
\text { Kolmogorov- } \\
\text { Smirnov }\end{array}$ & Sig. \\
\hline $\begin{array}{c}\text { Unstandardized } \\
\text { residual }\end{array}$ & 0,755 & 0,619 \\
\hline Sumber: Data primer diolah $(2015)$ &
\end{tabular}

Sumber: Data primer diolah (2015)

Berdasarkan Tabel 1, diperoleh nilai signifikansi uji normalitas Kolmogorov Smirnov pada unstandardized residual sebesar 0,619. Hasil ini menunjukkan nilai signifikansi dari unstandardized residual adalah lebih besar dari $\alpha(0,05)$, sehingga menunjukkan data dari variabel-variabel penelitian berdistribusi menurut distribusi normal.

b. Uji Multikolinieritas

Multikolinieritas terjadi apabila terdapat hubungan yang sempurna atau hampir sempurna antara variabel-variabel independen, sehingga sulit untuk memisahkan pengaruh tiap-tiap variabel itu secara individu terhadap variabel dependen. Gejala terjadinya hubungan multikolinieritas dapat diketahui dengan menggunakan nilai VIF (Variance Inflation Factor) yang didapat jika menggunakan program SPSS. Multikolinier terjadi jika nilai VIF masingmasing variabel lebih dari 10 . 
Tabel 2. Hasil Uji Multikolinieritas

\begin{tabular}{lcc}
\hline \multicolumn{1}{c}{ Variabel } & Toleransi & VIF \\
\hline $\begin{array}{l}\text { Tingkat pendapatan } \\
\left(\mathrm{X}_{1}\right)\end{array}$ & 0,101 & 9,907 \\
$\begin{array}{l}\text { Harga daging sapi } \\
\left(\mathrm{X}_{2}\right)\end{array}$ & 0,101 & 9,902 \\
$\begin{array}{l}\text { Harga daging ayam } \\
\left(\mathrm{X}_{3}\right)\end{array}$ & 0,206 & 4,865 \\
$\begin{array}{l}\text { Jumlah penduduk } \\
\left(\mathrm{X}_{4}\right)\end{array}$ & 0,109 & 9,169 \\
$\begin{array}{l}\text { Produksi daging sapi } \\
\left(\mathrm{X}_{5}\right)\end{array}$ & 0,853 & 1,172 \\
Populasi sapi $\left(\mathrm{X}_{5}\right)$ & 0,242 & 4,126 \\
\hline Sumber: Data primer diolah $(2015)$ &
\end{tabular}

Berdasarkan Tabel 2, diperoleh nilai VIF pada masing-masing variabel yaitu variabel tingkat pendapatan $\left(\mathrm{X}_{1}\right)$ sebesar 9,907, variabel harga daging sapi $\left(\mathrm{X}_{2}\right)$ sebesar 9,902, variabel harga daging ayam $\left(\mathrm{X}_{3}\right)$ sebesar 4,865, variabel jumlah penduduk $\left(\mathrm{X}_{4}\right)$ sebesar 9,169, variabel produksi daging sapi $\left(\mathrm{X}_{5}\right)$ sebesar 1,172 dan variabel populasi sapi $\left(\mathrm{X}_{6}\right)$ sebesar 4,126 . Hasil ini menunjukkan nilai VIF dari masing-masing variabel independen adalah kurang dari 10, sehingga pada variabelvariabel independen tidak terjadi multikolinier.

c. Uji Autokorelasi

Dari uji autokorelasi yang dilakukan, maka nilai Durbin-Watson Test diketahui sebesar 1,566 dan berada pada kisaran 1,552,46 . Berdasarkan nilai tersebut, maka dapat disimpulkan bahwa model regresi di atas tidak terdapat autokorelasi.

\section{d. Uji Heteroskedastisitas}

Heteroskedastisitas terjadi apabila distribusi probabilitas tetap sama (konstan) dalam semua observasi variabel independen dan varians setiap residual adalah sama untuk semua nilai dari variabel independen. Uji heteroskedastisitas yang digunakan adalah uji Glesjer, yaitu dengan meregresikan nilai absolut residual terhadap masing-masing variabel independen

Diperoleh nilai t-hitung dari masingmasing variabel adalah tingkat pendapatan $\left(X_{1}\right)$ sebesar $0,086(\mathrm{p}=0,932)$, harga daging sapi $\left(\mathrm{X}_{2}\right)$ sebesar $1,140(\mathrm{p}=0,263)$, harga daging ayam $\left(\mathrm{X}_{3}\right)$ sebesar $0,110(\mathrm{p}=0,913)$, jumlah penduduk $\left(\mathrm{X}_{4}\right)$ sebesar $-1,658(\mathrm{p}=$
$0,107)$, produksi $\mathrm{d}, 168)$ dan populasi sapi $\left(\mathrm{X}_{6}\right)$ sebesar $1,379(\mathrm{p}=0,177)$, sedangkan nilai t-tabel uji ini adalah sebesar 2,035. Hal ini berarti masing-masing variabel independen tidak berpengaruh signifikan terhadap nilai absolut residual, yang menunjukkan bahwa dalam penelitian ini tidak terjadi heteroskedastisitas antar variabel independen.

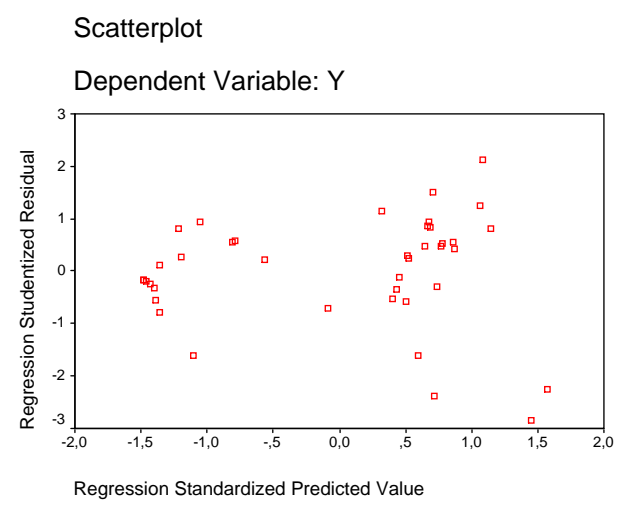

Gambar 1. Hasil uji heteroskedastisitas dengan metode scatter plot

Berdasarkan Gambar 1 menunjukkan bahwa tidak terdapat pola tertentu yang diperlihatkan oleh titik dalam gambar, sehingga dapat disimpulkan bahwa tidak terdapat gejala heteroskedastisitas pada semua observasi variabel independen dan varians setiap residual.

Berdasarkan teori permintaan menunjukkan bahwa semakin tinggi harga, maka permintaan akan barang tersebut semakin berkurang, tetapi kondisi yang terjadi saat ini di Kabupaten Jember bertolak belakang dengan teori ini. Konsumsi terhadap daging sapi semakin meningkat meskipun harga daging sapi yang juga semakin meningkat.

Faktor-faktor yang diduga berpengaruh terhadap permintaan daging sapi (Y) antara lain: tingkat pendapatan $\left(\mathrm{X}_{1}\right)$, harga daging sapi $\left(\mathrm{X}_{2}\right)$, harga daging ayam $\left(\mathrm{X}_{3}\right)$, jumlah penduduk $\left(\mathrm{X}_{4}\right)$, produksi daging sapi $\left(\mathrm{X}_{5}\right)$ dan jumlah populasi sapi $\left(\mathrm{X}_{6}\right)$. Pengujian dari faktor-faktor yang berpengaruh terhadap permintaan daging sapi menggunakan model regresi linier berganda dengan menggunakan metode enter. Analisis regresi linier berganda memberikan hasil persamaan regresi linier berganda sebagai berikut : 


\section{$Y=1897866-23,354 X_{1}+6,362 X_{2}+21,397 X_{3}-$ $0,641 X_{4}+8,686 X_{5}+0,762 X_{6}$}

Hasil uji $F$ menunjukkan nilai $F-$ hitung sebesar 26,916 dengan tingkat signifikan sebesar 0,000 . Nilai signifikansi $(0,000)$ lebih kecil dibandingkan dengan $\alpha$ $(0,05)$, artinya terdapat pengaruh signifikan secara bersama-sama antara variabel independen dan variabel dependen.

Nilai konstanta sebesar 1897866 menunjukkan bahwa permintaan daging sapi di Kabupaten Jember adalah sebesar $1.897 .866 \mathrm{~kg} /$ tahun pada saat faktor-faktor lain di dalam model yang mempengaruhinya sama dengan nol. Nilai koefisien determinasi $\left(\mathrm{R}^{2}\right)$ sebesar 0,830 menunjukkan bahwa variabel bebas (tingkat pendapatan, harga daging sapi, harga daging ayam, jumlah penduduk, produksi daging sapi dan populasi sapi) berpengaruh terhadap permintaan daging sapi di Kabupaten Jember sebesar 83,0\% sedangkan sisanya sebesar $17,0 \%$ dipengaruhi oleh faktorfaktor lain yang tidak terdapat dalam model penelitian.

Untuk mengetahui pengaruh hubungan masing-masing variabel bebas $\left(\mathrm{X}_{1}, \mathrm{X}_{2}, \mathrm{X}_{3}\right.$, $\mathrm{X}_{4}, \mathrm{X}_{5}, \mathrm{X}_{6}$ ), maka sesuai dengan tujuan penelitian hasil uji sidik ragam (Uji-F) perlu dilanjutkan pada uji parsial (Uji t) seperti yang disajikan pada penjelasan sebagai berikut :

\section{Tingkat Pendapatan $\left(\mathbf{X}_{1}\right)$}

Tingkat pendapatan adalah jumlah pendapatan konsumen dalam periode tertentu yang dinyatakan dalam satuan ribu rupiah/kapita/tahun. Hasil analisis data diperoleh nilai koefisien regresi variabel tingkat pendapatan bernilai negatif sebesar 23,354 . Hal ini berarti bahwa dengan asumsi variabel-variabel yang lain konstan, setiap penambahan tingkat pendapatan sebesar $1.000 \mathrm{rupiah} / \mathrm{kapita} / \mathrm{tahun}$, maka permintaan daging sapi akan mengalami penurunan sebesar 23,254 kg/tahun. Sedangkan hasil uji $\mathrm{t}$ diperoleh nilai t-hitung untuk variabel tingkat pendapatan sebesar -2,259 dengan nilai signifikansi sebesar 0,031 . Nilai signifikansi sebesar 0,031 lebih kecil daripada $\alpha(0,05)$. Hal ini menunjukkan bahwa secara parsial tingkat pendapatan konsumen berpengaruh nyata terhadap permintaan daging sapi.

Hasil penelitian menunjukkan bahwa semakin besar tingkat pendapatan, maka permintaan akan daging sapi justru semakin menurun. Diduga dengan adanya tingkat pendapatan yang semakin tinggi, konsumen akan cenderung memilih makanan yang lebih bervariasi dan bergizi. Jadi makanan yang dikonsumsi cenderung dipilih yang bervariasi dan bergizi tidak harus dengan mengkonsumsi daging sapi. Menurut Sajogyo (1997), pendapatan seseorang sangat berpengaruh terhadap pemilihan pangan yang akan dikonsumsi. Pendapatan yang semakin tinggi akan menyebabkan semakin baik juga seseorang dalam memilih pangan yang dikonsumsi. Menurut Aziz (2009) bahwa pendapatan yang tinggi dapat mempengaruhi konsumsi terhadap barang atau jasa, hal ini dikarenakan keinginan konsumen untuk menabung sebagian uangnya untuk mendapatkan keinginan jangka panjang.

\section{Harga Daging Sapi $\left(\mathrm{X}_{2}\right)$}

Harga daging sapi adalah daging sapi yang dijual dan dibeli oleh konsumen yang dinyatakan dalam satuan rupiah/ $/ \mathrm{kg} / \mathrm{tahun}$. Kebutuhan akan daging sapi oleh konsumen dipengaruhi oleh harga daging sapi. Secara teori permintaan, jika harga meningkat, maka permintaan akan menurun. Hasil analisis data diperoleh nilai koefisien regresi variabel harga daging sapi bernilai positif sebesar 23,895 . Hal ini berarti bahwa dengan asumsi variabel-variabel yang lain konstan, setiap kenaikan harga daging sapi sebesar Rp 1.000 , maka permintaan daging sapi akan mengalami peningkatan sebesar 23,895 $\mathrm{kg} /$ tahun. Sedangkan hasil uji t diperoleh nilai t-hitung untuk variabel harga daging sapi sebesar 0,715 dengan nilai signifikansi sebesar 0,001. Nilai signifikansi sebesar 0,495 lebih besar daripada $\alpha(0,05)$. Hal ini menunjukkan bahwa secara parsial harga daging sapi berpengaruh tidak nyata terhadap permintaan daging sapi.

\section{Harga Daging Ayam $\left(X_{3}\right)$}

Harga daging ayam adalah daging ayam yang dijual dan dibeli oleh konsumen yang dinyatakan dalam satuan ribu rupiah/kg/tahun). Nilai koefisien regresi yang diperoleh untuk variabel harga daging 
ayam bernilai positif sebesar 21,397 . Hal ini berarti bahwa setiap kenaikan harga daging ayam sebesar $\mathrm{Rp} 1.000,-$, maka permintaan daging sapi akan meningkat sebesar 21,397 $\mathrm{kg} /$ tahun dengan asumsi faktor lain dianggap konstan. Sedangkan hasil uji t diperoleh nilai t-hitung untuk variabel harga daging ayam sebesar 4,608 dengan nilai signifikansi sebesar 0,000. Nilai signifikansi sebesar 0,000 lebih kecil daripada $\alpha(0,05)$. Hal ini menunjukkan bahwa secara parsial harga daging ayam berpengaruh nyata terhadap permintaan daging sapi.

Peningkatan atau penurunan harga daging ayam akan mempengaruhi permintaan daging sapi. Secara umum bila harga daging ayam meningkat, maka permintaan akan daging ayam akan menurun. Daging sapi yang merupakan barang substitusi dari daging ayam, maka akan mengalami peningkatan dalam hal permintaannya. Jadi hubungan antara harga daging ayam ini searah dengan permintaan daging sapi. Menurut Sukirno (2002), sesuatu barang dinamakan barang pengganti (substitusi) kepada sesuatu barang lain apabila ia dapat menggantikan fungsi dari barang lain tersebut. Harga barang pengganti dapat mempengaruhi permintaan barang yang dapat digantikannya. Sekiranya harga barang pengganti bertambah murah, maka barang yang digantikannya akan mengalami pengurangan dalam permintaan.

\section{Jumlah Penduduk $\left(X_{4}\right)$}

Jumlah penduduk adalah jumlah dimana penduduk tinggal dalam suatu daerah yang dinyatakan dalam satuan jiwa/tahun. Hasil analisis data diperoleh nilai koefisien regresi variabel jumlah penduduk bernilai negatif sebesar 0,641 . Hal ini berarti bahwa dengan asumsi variabelvariabel yang lain konstan, setiap penambahan jumlah penduduk sebesar 1 jiwa/tahun, maka permintaan daging sapi akan mengalami penurunan sebesar 0,641 $\mathrm{kg} /$ tahun. Sedangkan hasil uji t diperoleh nilai t-hitung untuk variabel jumlah penduduk sebesar $-2,027$ dengan nilai signifikansi sebesar 0,051 . Nilai signifikansi sebesar 0,051 lebih besar daripada $\alpha(0,05)$. Hal ini menunjukkan bahwa secara parsial jumlah penduduk berpengaruh tidak nyata terhadap permintaan daging sapi.
Indikasi yang diambil jika dikaitkan dengan konsumsi daging sapi untuk usia 015 tahun belum dapat dikatakan konsumen yang menginginkan daging sapi, karena secara kebutuhan makanan lebih banyak mengkonsumsi susu, roti dan makanan ringan lainnya. Indikasi yang selanjutnya dapat dinyatakan yaitu dengan melihat kondisi umur 46-75 ke atas bahwa para konsumen mengurangi konsumsi untuk mencegah terjadinya penyakit kolesterol yang memang pada umumnya menyerang masyarakat usia 40 tahun ke atas. Sehingga indikasi ini juga menjadi alasan bahwa jumlah penduduk tidak berpengaruh secara nyata akan permintaan daging sapi di Kabupaten Jember

\section{Produksi Daging Sapi $\left(X_{5}\right)$}

Produksi daging sapi adalah tingkat ketersediaan daging sapi yang dinyatakan dalam satuan ton/tahun. Hasil analisis data diperoleh nilai koefisien regresi variabel produksi daging sapi bernilai positif sebesar 0,762 . Hal ini berarti bahwa dengan asumsi variabel-variabel yang lain konstan, setiap kenaikan produksi daging sapi sebesar 1 ton/tahun, maka permintaan daging sapi akan mengalami peningkatan sebesar 0,762 $\mathrm{kg} /$ tahun. Sedangkan hasil uji t diperoleh nilai t-hitung untuk variabel produksi daging sapi sebesar 0,088 dengan nilai signifikansi sebesar 0,931. Nilai signifikansi sebesar 0,931 lebih besar daripada $\alpha(0,05)$. Hal ini menunjukkan bahwa secara parsial produksi daging sapi berpengaruh tidak nyata terhadap permintaan daging sapi.

Permintaan akan daging sapi meningkat seiring dengan meningkatnya produksi daging sapi. Produk peternakan umumnya memiliki harga yang relatif tinggi dibandingkan dengan komoditas pertanian lainnya, permintaan produk peternakan berkaitan erat dengan daya lebih konsumen.

\section{Populasi Sapi $\left(\mathbf{X}_{4}\right)$}

Populasi sapi adalah jumlah sapi yang dipelihara pada periode tertentu yang dinyatakan dalam satuan ekor/tahun. Nilai koefisien regresi yang diperoleh untuk variabel jumlah populasi sapi bernilai positif sebesar 0,762. Hal ini berarti bahwa setiap kenaikan jumlah populasi sapi sebesar satu ekor/tahun, maka permintaan daging sapi akan meningkat sebesar 0,762 kg/tahun 
dengan asumsi faktor lain dianggap konstan. Sedangkan hasil uji t diperoleh nilai t-hitung untuk variabel jumlah populasi sapi sebesar 2,248 dengan nilai signifikansi sebesar 0,031 . Nilai signifikansi sebesar 0,031 lebih kecil daripada $\alpha(0,05)$. Hal ini menunjukkan bahwa secara parsial jumlah populasi sapi berpengaruh nyata terhadap permintaan daging sapi.

Populasi sapi sangat identik dengan produksi daging sapi, jika populasi sapi semakin bertambah tentunya produksi dari daging sapi juga akan meningkat. Keberadaan sapi adalah sebagai penyedia bahan pangan maupun sebagai sumber pendapatan dan keduanya berperan dalam meningkatkan ketersediaan dan aksebilitas pangan. Kabupaten Jember merupakan salah satu sentra peternakan sapi yang dianggap mampu memproduksi daging sapi sendiri tanpa harus melakukan impor dari luar kota. Menurut Umiyasih (2004), pengembangan potensi dilaksanakan untuk meningkatkan kontribusinya dalam penyediaan daging untuk memenuhi kebutuhan masyarakat yang terus meningkat.

\section{Faktor-Faktor yang Mempengaruhi Perilaku Konsumen Rumah Tangga untuk Mengkonsumsi Daging Sapi Kabupaten Jember}

Terdapat 15 variabel yang dianalisis berpengaruh terhadap perilaku konsumen dalam mengkonsumsi daging sapi yaitu sebagai berikut: variabel pekerjaan $\left(\mathrm{X}_{1}\right)$, variabel keadaan ekonomi $\left(\mathrm{X}_{2}\right)$, variabel keluarga $\left(\mathrm{X}_{3}\right)$, variabel kepribadian $\left(\mathrm{X}_{4}\right)$, variabel kebudayaan $\left(\mathrm{X}_{5}\right)$, variabel sub-budaya $\left(\mathrm{X}_{6}\right)$, variabel kelas sosial $\left(\mathrm{X}_{7}\right)$, variabel referensi $\left(\mathrm{X}_{8}\right)$, variabel persepsi $\left(\mathrm{X}_{9}\right)$, variabel peran $\left(\mathrm{X}_{10}\right)$, variabel kepercayaan $\left(\mathrm{X}_{11}\right)$, variabel umur $\left(\mathrm{X}_{12}\right)$, variabel gaya hidup $\left(\mathrm{X}_{13}\right)$, variabel motivasi $\left(\mathrm{X}_{14}\right)$ dan variabel proses belajar $\left(\mathrm{X}_{15}\right)$. Variabel-variabel tersebut akan dikelompokan kemudian, dilakukan proses analisis faktor. Terdapat 4 tahapan dalam melakukan analisis faktor untuk mengetahui faktor-faktor yang mempengaruhi perilaku konsumen daging sapi, tahapan tersebut yaitu:

1. Pengujian Standar Deviasi

2. Uji KMO (Kaiser-Meyer-Olki) and Bartlett's Test dan
3. Menyederhanakan variabel menggunakan metode PCA

4. Analisis Faktor

\section{a. Pengujian Standar Deviasi}

Suatu pengujian dilakukan bila sebuah variabel memiliki kecenderungan untuk mengelompok dan membentuk suatu faktor. Variabel tersebut akan berkorelasi kuat dengan variabel lain. Sebaliknya, jika antar variabel memiliki korelasi yang lemah maka variabel tersebut tidak akan mengelompok dalam faktor tertentu. Pada Tabel 3 dapat dilihat hasil pengujian standar deviasi dari keempat belas variabel.

Tabel 3. Hasil Pengujian Standar Deviasi

\begin{tabular}{|c|c|c|c|c|}
\hline Variabel & Min & Max & Mean & SD \\
\hline $\begin{array}{l}\text { Pekerjaan } \\
\left(\mathrm{X}_{1}\right)\end{array}$ & 2 & 5 & 3,800 & 0,838 \\
\hline Keadaan & & & & \\
\hline $\begin{array}{l}\text { Ekonomi } \\
\left(\mathrm{X}_{2}\right)\end{array}$ & 1 & 5 & 3,400 & 1,115 \\
\hline $\begin{array}{l}\text { Keluarga } \\
\left(\mathrm{X}_{3}\right)\end{array}$ & 2 & 5 & 4,053 & 0,957 \\
\hline $\begin{array}{l}\text { Kepribadian } \\
\left(\mathrm{X}_{4}\right)\end{array}$ & 1 & 5 & 3,187 & 1,099 \\
\hline $\begin{array}{l}\text { Kebudayaan } \\
\left(\mathrm{X}_{5}\right)\end{array}$ & 1 & 5 & 3,973 & 0,944 \\
\hline $\begin{array}{l}\text { Sub-budaya } \\
\left(\mathrm{X}_{6}\right)\end{array}$ & 2 & 5 & 3,787 & 0,963 \\
\hline $\begin{array}{l}\text { Kelas Sosial } \\
\left(\mathrm{X}_{7}\right)\end{array}$ & 1 & 5 & 2,920 & 0060 \\
\hline $\begin{array}{l}\text { Referensi } \\
\left(\mathrm{X}_{8}\right)\end{array}$ & 1 & 5 & 947 & 0,751 \\
\hline Persepsi $\left(\mathrm{X}_{9}\right)$ & 1 & 4 & 2,600 & 0,854 \\
\hline Peran $\left(X_{10}\right)$ & 1 & 5 & 3,120 & 0,869 \\
\hline $\begin{array}{l}\text { Kepercayaan } \\
\left(\mathrm{X}_{11}\right)\end{array}$ & 2 & 5 & 3,720 & 068 \\
\hline Umur $\left(\mathrm{X}_{12}\right)$ & 1 & 4 & 2,627 & 0,927 \\
\hline $\begin{array}{l}\text { Gaya Hidup } \\
\left(\mathrm{X}_{13}\right)\end{array}$ & 2 & 5 & 3,413 & 0,91 \\
\hline
\end{tabular}

$\begin{array}{lllll}\text { Motivasi } & 1 & 5 & 3,267 & 0,977 \\ \left(X_{14}\right) & & & \end{array}$

$\begin{array}{lllll}\text { Proses } & 1 & 5 & 3,493 & 0,978 \\ \text { Belajar }\left(\mathrm{X}_{15}\right) & 1 & & \end{array}$

Sumber: data primer diolah (2015)

Hasil Tabel 3 dapat dilihat bahwa nilai standar deviasi tiap variabel berada di atas nol (0) sehingga tidak ada atribut variabel yang harus dikeluarkan. Hasil ini menunjukkan bahwa semua atribut variabel di atas dibutuhkan dalam melihat perilaku 
konsumen daging sapi di Jember. Dapat disimpulkan bahwa atribut variabel di atas layak untuk dianalisis secara statistik dan dapat dilakukan analisis faktor untuk menguji kelayakan atribut variabel dengan melihat nilai KMO and Bartlett's Test serta nilai MSA. Variabel keadaan ekonomi $\left(\mathrm{X}_{2}\right)$ memiliki nilai standar deviasi paling tinggi yaitu sebesar 1,115 sehingga variabel keadaan ekonomi merupakan variabel yang paling dibutuhkan di antara variabel-variabel lainnya dalam melihat perilaku konsumen daging sapi, sedangkan variabel kepercayaan $\left(\mathrm{X}_{11}\right)$ memiliki nilai standar deviasi paling kecil 0,689 sehingga dapat diartikan variabel kepercayaan mempunyai pengaruh kecil dalam melihat perilaku konsumen daging sapi di Kota Jember.

\section{b. Uji KMO and Bartlett's Test}

Angka MSA pada uji KMO and Bartlett's Test digunakan untuk menguji dan mengukur hubungan antar semua indikator yang digunakan. Hasil uji KMO and Bartlett's Test pertama disajikan pada Tabel 4.

Tabel 4. Hasil Uji KMO and Bartlett's Test

\begin{tabular}{|c|c|c|}
\hline \multicolumn{2}{|c|}{$\begin{array}{l}\text { Kaiser-Meyer-Olkin Measure } \\
\text { of Sampling Adequacy. }\end{array}$} & 0,560 \\
\hline \multirow{3}{*}{$\begin{array}{l}\text { Bartlett's } \\
\text { Test of } \\
\text { Sphericity }\end{array}$} & $\begin{array}{l}\text { Approx. Chi- } \\
\text { Square }\end{array}$ & 175,21 \\
\hline & Df & 105 \\
\hline & Sig. & 0,000 \\
\hline
\end{tabular}

Hasil dari Uji KMO and Bartlett's Test yang pertama menunjukkan nilai MSA (Measures of Sampling Adequacy) sebesar 0,560. Artinya angka KMO and Bartlett's Test adalah 0,560 dengan signifikansi 0,000. Oleh karena angka tersebut sudah di atas 0,5 dengan signifikansi di bawah 0,05, maka variabel dan sampel yang ada sudah dapat dianalisis lebih lanjut. Setelah itu melihat hasil analisis MSA pada Uji KMO pertama untuk mengetahui apakah terdapat variabel yang dikeluarkan dari model untuk uji selanjutnya.
Tabel 5. Hasil Analisis Measures of Sampling Adequacy pada Uji KMO

\begin{tabular}{lc}
\hline Variabel & Nilai MSA \\
\hline Pekerjaan $\left(\mathrm{X}_{1}\right)$ & 0,5889 \\
Keadaan Ekonomi $\left(\mathrm{X}_{2}\right)$ & 0,5018 \\
Keluarga $\left(\mathrm{X}_{3}\right)$ & 0,5169 \\
Kepribadian $\left(\mathrm{X}_{4}\right)$ & 0,5043 \\
Kebudayaan $\left(\mathrm{X}_{5}\right)$ & 0,5864 \\
Sub-budaya $\left(\mathrm{X}_{6}\right)$ & 0,7239 \\
Kelas Sosial $\left(\mathrm{X}_{7}\right)$ & 0,5421 \\
Referensi $\left(\mathrm{X}_{8}\right)$ & 0,5244 \\
Persepsi $\left(\mathrm{X}_{9}\right)$ & 0,5096 \\
Peran $\left(\mathrm{X}_{10}\right)$ & 0,5973 \\
Kepercayaan $\left(\mathrm{X}_{11}\right)$ & 0,5857 \\
Umur $\left(\mathrm{X}_{12}\right)$ & 0,5466 \\
Gaya Hidup $\left(\mathrm{X}_{13}\right)$ & 0,5736 \\
Motivasi $\left(\mathrm{X}_{14}\right)$ & 0,6176 \\
Proses Belajar $\left(\mathrm{X}_{15}\right)$ & 0,5022 \\
\hline Sumber: Data primer diolah (2015) &
\end{tabular}

Berdasarkan Tabel 5, nilai Measures of Sampling Adequacy beberapa variabel memiliki nilai terkecil sebesar 0,5018 pada variabel keadaan ekonomi $\left(\mathrm{X}_{2}\right)$. Hal ini menunjukkan bahwa nilai Measures of Sampling Adequacy dari variabel-variabel sudah lebih dari 0,5, maka variabel dan sampel yang ada sudah dapat melakukan tahapan analisis selanjutnya yaitu tahapan analisis faktor.

Terdapat enam Component Matrix yang sesuai dengan jumlah faktor yang didapat. Pengelompokan variabel yang membentuk faktor-faktor dari rotasi yang telah dilakukan. Kemudian didapat lima belas variabel yang mengelompok menjadi enam faktor, yaitu:

- Faktor 1: Kebudayaan $\left(\mathrm{X}_{5}\right)$, subbudaya $\left(\mathrm{X}_{6}\right)$ dan kepercayaan $\left(\mathrm{X}_{11}\right)$ dapat diberi identitas yang mewakili seluruh variabel dengan nama Faktor Budaya.

- Faktor 2: Pekerjaan $\left(\mathrm{X}_{1}\right)$, keadaan ekonomi $\left(\mathrm{X}_{2}\right)$, kelas sosial $\left(\mathrm{X}_{7}\right)$ dan umur $\left(\mathrm{X}_{12}\right)$ dapat diberi identitas yang mewakili seluruh variabel dengan nama Faktor Karakter Eksternal Konsumen.

- Faktor 3: Keluarga $\left(\mathrm{X}_{3}\right)$, referensi $\left(\mathrm{X}_{8}\right)$, peran $\left(\mathrm{X}_{10}\right)$ dan proses belajar $\left(\mathrm{X}_{15}\right)$ dapat diberi identitas yang mewakili 
seluruh variabel dengan nama Faktor Sosial.

- Faktor 4: Persepsi $\left(\mathrm{X}_{9}\right)$ dapat diberi identitas yang mewakili seluruh variabel dengan nama Faktor Persepsi.

- Faktor 5: Kepribadian $\left(\mathrm{X}_{4}\right)$ dan gaya hidup $\left(\mathrm{X}_{13}\right)$ dapat diberi identitas yang mewakili seluruh variabel dengan nama Faktor Pribadi.

- Faktor 6: Motivasi $\left(\mathrm{X}_{14}\right)$ dapat diberi identitas yang mewakili seluruh variabel dengan nama Faktor Motivasi.

Untuk mengetahui faktor apa saja secara berurutan yang memiliki nilai varians dari yang tertinggi sampai dengan yang terkecil pada Tabel 6.

Tabel 6. Pengaruh Faktor terhadap varians

\begin{tabular}{cllc}
\hline \multirow{2}{*}{ Faktor } & \multicolumn{3}{c}{ Inisial Eigenvalue } \\
\cline { 2 - 4 } & Total & $\begin{array}{c}\% \\
\text { varians }\end{array}$ & $\begin{array}{c}\% \\
\text { Kumulatif }\end{array}$ \\
\hline 1 & 2,294 & 15,296 & 15,296 \\
2 & 2,082 & 13,879 & 29,175 \\
3 & 1,627 & 10,845 & 40,020 \\
4 & 1,409 & 9,393 & 49,413 \\
5 & 1,170 & 7,799 & 57,212 \\
6 & 1,077 & 7,183 & 64,395 \\
\hline \multicolumn{3}{l}{ Sumber: data primer diolah (2015) }
\end{tabular}

Berdasarkan Tabel 6, pengaruh faktorfaktor tersebut ditunjukkan melalui nilai total varians sebesar $64,395 \%$, yang artinya bahwa faktor-faktor yang berpengaruh terhadap konsumsi daging sapi di Kabupaten Jember dapat dijelaskan sebesar 64,395\% oleh faktor kondisi lingkungan, faktor karakter eksternal konsumen, sumber informasi, persepsi, psikologis konsumen dan motivasi. Sisanya dipengaruhi oleh faktor lain yang belum dimasukkan dalam model sebesar $35,605 \%$.

1. Faktor Budaya

Faktor 1 (Budaya), meliputi variabel kebudayaan $\left(\mathrm{X}_{5}\right)$, sub-budaya $\left(\mathrm{X}_{6}\right)$ dan kepercayaan $\left(\mathrm{X}_{11}\right)$. Persentase varians sebesar 15,296\% menunjukkan bahwa faktor budaya merupakan faktor dominan pertama di antara faktor-faktor yang berpengaruh terhadap perilaku konsumen daging sapi. Hal ini dikarenakan faktor kebudayaan, faktor sub-budaya dan faktor kepercayaan merupakan faktor yang timbul dari kondisi lingkungan konsumen tersebut, sehingga sebelum mendapat pengaruh dari orang lain atau konsumen lain, para konsumen lebih mengutamakan kondisi yang berdasarkan "Faktor Budaya". Kebudayaan berasal dari daerah, suku, lingkungan yang mendukung dan dipercaya oleh konsumen rumah tangga. Faktor kebudayaan memberikan pengaruh paling luas dan dalam tingkah laku konsumen.

Sub budaya mencakup kebangsaan, agama, kelompok ras dan wilayah geografis. Secara umum responden masih terpengaruh oleh budaya yang berasal dari daerah masing-masing dan menganggap budaya tersebut sebagai budaya yang turun-temurun untuk mengkonsumsi daging sapi pada momen tertentu, misalnya diwaktu hari raya besar ataupun mengadakan suatu hajatan tertentu.

Kepercayaan yang timbul dalam konsumen rumah tangga di Kabupaten Jember umumnya masih percaya jika daging sapi banyak mengandung zat-zat yang dapat memberikan gizi pada tubuh manusia. Daging sapi yang dikonsumsi pada umumnya sesuai dengan kebutuhan masingmasing konsumen.

\section{Faktor Karakter Eksternal Konsumen}

Faktor 2 (karakter eksternal konsumen) meliputi variabel Pekerjaan $\left(\mathrm{X}_{1}\right)$, keadaan ekonomi $\left(\mathrm{X}_{2}\right)$, kelas sosial $\left(\mathrm{X}_{7}\right)$ dan umur $\left(\mathrm{X}_{12}\right)$. Persentase varians sebesar $13,879 \%$ menunjukkan bahwa faktor karakter eksternal konsumen merupakan faktor dominan kedua di antara faktor-faktor yang berpengaruh terhadap perilaku konsumen daging sapi. Jenis pekerjaan konsumen mempengaruhi konsumen dalam melakukan pembelian daging sapi terutama dalam mengatur pengeluaran rumah tangga. Jenis pekerjaan nantinya akan berhubungan dengan tingkat pendapatan konsumen. Konsumen dengan penghasilan rendah tidak bisa membeli daging sapi kapan pun mereka mau karena dengan pengeluaran keluarga yang besar anggaran rumah tangga harus pintar diatur akan terpenuhi semuanya. Sedangkan masyarakat dengan penghasilan tinggi dapat membeli daging sapi kapanpun ketika mereka berselera mengkonsumsi daging sapi. Jadi dapat disimpulkan jenis pekerjaan konsumen yang berhubungan 
langsung dengan tingkat pendapatan menjadi bahan pertimbangan konsumen dalam mengkonsumsi daging sapi pedaging.

Keadaan ekonomi yang kurang baik akan membuat konsumsi akan daging sapi berkurang, sehingga gizi yang dibutuhkan pun juga kurang. Pada umunya konsumen yang keadaan ekonominya dianggap kurang mengkonsumsi daging sapi pada waktu tertentu, sehingga kebutuhan gizi dari daging sapi kurang, sebaliknya jika kondisi ekonomi yaang dianggap mampu biasanya mengkonsumsi daging sapi lebih banyak.

Konsumen cenderung menganggap kelas sosial sebagi hal yang mempengaruhi secara tidak langsung. Contoh yang mempengaruhi dan menjadi panutan adalah keluarga, yang merupakan sekelompok kecil kelas sosial yang ada disekitar kita.

Konsumen yang cenderung lanjut usia masih ada yang mengkonsumsi daging sapi dalam jumlah yang dianggap sama dengan konsumen yang usianya lebih muda, akan tetapi frekuensi konsumsi daging sapi oleh konsumen yang memiliki umur diatas 50 tahun berkurang dan tidak banyak seperti di usia muda. Setiap responden memiliki usia yang berbeda-beda. Konsumsi daging sapi dalam keluarga akan dipengaruhi umur setiap anggota keluarganya. Anggota keluarga pada golongan muda dan dewasa cenderung mengkonsumsi daging sapi lebih banyak. Hal ini dikarenakan pada umur tersebut merupakan masa-masa konsumen dengan aktivitas tinggi sehingga diperlukan asupan energi untuk aktivitasnya sehari-hari. Berbeda dengan konsumen golongan umur tua, biasanya cenderung mengurangi konsumsi daging sapi. Hal ini dikarenakan pada umur tersebut konsumen sudah menjaga pola makan demi kesehatan mereka serta nafsu makan yang mulai menurun. Selain itu pada golongan usia tua (50 tahun ke atas) sudah mulai rentan akan penyakit, jadi konsumen bertindak lebih hati-hati dalam mengkonsumsi makanan.

\section{Faktor Sosial}

Faktor 3 (sosial) yang meliputi keluarga $\left(\mathrm{X}_{3}\right)$, referensi $\left(\mathrm{X}_{8}\right)$, peran $\left(\mathrm{X}_{10}\right)$ dan proses belajar $\left(\mathrm{X}_{15}\right)$. Persentase varians sebesar $10,845 \%$ menunjukkan bahwa faktor sosial merupakan faktor dominan ketiga di antara faktor-faktor yang berpengaruh terhadap perilaku konsumen daging sapi. Keluarga merupakan lingkungan terdekat konsumen. Konsumsi daging sapi dalam suatu keluarga merupakan hal yang penting, karena dari keluarga seorang konsumen belajar dan dipengaruhi secara langsung maupun tidak langsung, khususnya dalam mengkonsumsi daging sapi.

Referensi merupakan suatu cara belajar konsumen dengan melihat pengalaman yang sudah terjadi, sehingga perlunya referensi untuk membeli daging sapi dari berbagai aspek, contoh: konsumen memilih bagian daging sapi yang memiliki nilai gizi yang baik, mencari harga daging sapi dengan survey ke beberapa pedagang yang ada di beberapa pasar untuk mencari harga daging sapi yang lebih murah.

Peran tidak sepenuhnya menjadi faktor utama untuk mempengaruhi konsumen membeli daging sapi, hal ini dikarenakan informasi yang didapat masih dipertimbangkan oleh konsumen. Contoh: seorang ibu rumah tangga yang melakukan pembelian tidak begitu memperhatikan informasi dari orang lain, hal ini dikarenakan ibu rumah tangga sudah mengerti kebutuhan yang ingin mereka beli terhadap daging sapi.

Proses belajar merupakan tindakan seorang konsumen yang belum memiliki pengalaman dalam membeli daging sapi yang sehat dan berkualitas. Pengalaman dijadikan sebagai acuan untuk mendapatkan suatu daging sapi yang bergizi dan berkualitas. Sifat konsumen yang cenderung melihat harga yang lebih murah membuat konsumen memilih bagian daging sapi di berbagai tempat yang dianggap lebih murah. Sebaliknya juga konsumen yang mengutamakan kualitas juga memilih bagian daging sapi yang dianggap memiliki gizi lebih diberbagai tempat. Sebelum melakukan suatu pembelian konsumen akan terlebih dahulu melakukan evaluasi terhadap produk yang akan dibelinya.

Evaluasi terhadap suatu produk salah satu yang dilihat oleh konsumen adalah keadaan produk. Daging sapi yang akan dibeli oleh konsumen harus memenuhi kriteria-kriteria persyaratan yang diantaranya memenuhi kualitas yang baik, 
segar, harga masih terjangkau dan informasi paling baru dari daging sapi.

4. Faktor Persepsi

Faktor 4 (persepsi) yang meliputi persepsi $\left(\mathrm{X}_{9}\right)$. Persentase varians sebesar 9,393\% menunjukkan bahwa faktor persepsi merupakan faktor dominan keempat di antara faktor-faktor yang berpengaruh terhadap perilaku konsumen daging sapi. Persepsi adalah proses yang digunakan oleh seorang individu untuk memilih, mengorganisasi dan menginterpretasi masukan-masukan informasi guna menciptakan informasi guna menciptakan gambaran dunia yang memiliki arti (Sunarto, 2004). Persepsi dalam konsumen daging sapi diartikan sebagai penilaian terhadap daging sapi. Konsumen rumah tangga lebih memiliki pengetahuan sendiri akan kebutuhan daging sapi yang dibutuhkan, selain itu yang lebih banyak mempengaruhi adalah kepentingan keluarga bukan ajakan dari orang lain. Persepsi terhadap daging sapi umumnya hanya melihat daging sapi secara fisik. Daging sapi yang dianggap sesuai dengan persepsi konsumen akan dibeli dan dikonsumsi.

5. Faktor Pribadi

Faktor 5 (pribadi) yang meliputi kepribadian $\left(\mathrm{X}_{4}\right)$ dan gaya hidup $\left(\mathrm{X}_{13}\right)$. Persentase varians sebesar 7,799\% menunjukkan bahwa faktor pribadi merupakan faktor dominan kelima di antara faktor-faktor yang berpengaruh terhadap perilaku konsumen daging sapi. Fakta yang terjadi kepribadian seseorang yang berbeda satu sama lain membuat setiap keputusan yang diambil berbeda dalam pembelian daging sapi. Setiap orang mempunyai karakteristik pribadi yang mempengaruhi perilaku pembeliannya. Kepribadian yang dimaksudkan adalah sekumpulan sifat psikologis manusia yang menyebabkan respons yang relatif konsisten dan tahan lama terhadap rangsangan lingkungan (termasuk perilaku pembelian). Kepribadian juga dapat menjadi variabel yang berguna dalam menganalisis pilihan merek konsumen. Kepribadian merek (brand personality) dapat didefinisikan sebagai bauran tertentu dari sifat manusia yang dapat kita kaitkan pada merek tertentu. Pada umumnya kepribadian responden daging sapi mengarah menuju konsumsi terhadap daging yang lebih murah dan diikuti dengan jenis daging sapi yang masih layak dikonsumsi.

Gaya hidup konsumen merupakan pola hidup di dunia yang diekspresikan oleh kegiatan. Fakta yang terjadi banyak yang menganggap gaya hidup konsumen dengan mengkonsumsi daging sapi lebih menyehatkan daripada daging kambing atua daging lainnya, sehingga pola konsumsi daging sapi terbentuk dalam jangka waktu tertentu. Gaya hidup konsumen memotret interaksi "seseorang secara utuh" dengan lingkungannya. Menurut Engel (1994), Keputusan konsumen juga dipengaruhi oleh nilai inti (core values), sistem kepercayaan yang mendasari sikap dan perilaku. Nilai inti lebih dalam daripada perilaku atau sikap dan menentukan pilihan dan keinginan seseorang pada tingkat dasar dalam jangka panjang. Pada umumnya responden yang mengkonsumsi daging sapi mengkonsumsi daging sapi karena memandang dari sisi kebutuhan gizi dari daging sapi, selain itu konsumsi daging sapi diolah sesuai dengan jenis makanan baru yang berbahan dasar daging sapi (beef).

6. Faktor Motivasi

Faktor 6 (motivasi) yang meliputi motivasi $\left(\mathrm{X}_{14}\right)$. Persentase varians sebesar 7,183\% menunjukkan bahwa faktor motivasi merupakan faktor dominan keenam di antara faktor-faktor yang berpengaruh terhadap perilaku konsumen daging sapi. Menurut Schiffman dan Kanuk (2008:72), motivasi dapat digambarkan sebagai tenaga pendorong dalam diri individu yang memaksa mereka untuk bertindak. Tenaga pendorong tersebut dihasilkan oleh keadaan tertekan, yang timbul sebagai akibat kebutuhan yang tidak terpenuhi. Kebutuhan menjadi motif (motive) ketika kebutuhan itu meningkat sampai tingkat intensitas yang cukup sehingga mendorong kita bertindak. Motivasi dua arah, kita memilih satu tujuan di atas tujuan lainnya dan intensitas energi yang digunakan untuk mengejar tujuan.

Motivasi yang terjadi pada konsumen daging sapi di Kabupaten Jember pada umumnya merupakan motivasi yang timbul karena suatu keinginan sendiri yang ingin memenuhi kebutuhan bukan karena 
kepuasan. Misalkan konsumsi daging sapi pada saat hari besar umat Islam. Hal ini dilakukan karena pada saat itu kebutuhan akan daging sapi sudah menjadi kebiasaan, karena lingkungan mereka yang masih bergantung pada tradisi daerah masingmasing. Oleh karenanya konsumen termotivasi untuk mengkonsumsi daging sapi demi mencapai kebutuhan pada momen tersebut. Sedangkan pada hari-hari biasa konsumsi akan daging sapi tidak dibutuhkan setiap hari, akan tetapi dikonsumsi sebagai penunjang kebutuhan gizi dari tubuh manusia, sehingga konsumen daging sapi tidak mengkonsumsi untuk mencapai kepuasan, akan tetapi lebih ke arah kebutuhan gizi yang dibutuhkan tubuh manusia.

\section{Preferensi Konsumen Rumah Tangga terhadap Daging Sapi yang Dikonsumsi di Kabupaten Jember}

Konsumen daging sapi yang semakin meningkat menyebabkan banyaknya jumlah pedagang daging sapi di Kabupaten Jember, khususnya di tiga pasar yaitu, Pasar Tanjung, Pasar Mayang dan Pasar Mangli. Konsumen memiliki banyak peluang untuk memilih daging yang sesuai dengan kebutuhan mereka.

Variabel yang menjadi preferensi atau pilihan konsumen terhadap konsumsi daging sapi di Kabupaten Jember, yaitu warna daging sapi, kandungan lemak daging sapi dan bagian daging sapi. Jumlah data responden sebesar 75 orang mewakili 3 pasar yaitu, Pasar Tanjung, Pasar Mayang dan Pasar Mangli yang merupakan tempat penelitian didapatkan dengan hasil perhitungan pada Tabel 7.

Tabel 7 menjelaskan tentang keyakinan dan evaluasi terhadap daging sapi. Analisis Fishbein Multiatribut menunjukkan bahwa pada analisis belief (Kepercayaan) bahwa, atribut daging sapi yang diyakini paling disukai oleh konsumen adalah "bagian daging sapi", karena memiliki nilai kepercayaan terbesar 4,05. Artinya konsumen mempunyai kepercayaan bahwa "bagian daging sapi" paling disukai konsumen.
Tabel 7. Hasil Analisis Multiatribut Fishbein

\begin{tabular}{|c|c|c|c|}
\hline \multirow[b]{2}{*}{ Atribut } & \multicolumn{2}{|c|}{ Skala Analisis } & \multirow[b]{2}{*}{$\begin{array}{c}\text { Skor Sikap } \\
\quad\left(\mathrm{A}_{0}\right)\end{array}$} \\
\hline & $\begin{array}{l}\text { Keper } \\
\text { cayaa } \\
\text { n (bi) }\end{array}$ & $\begin{array}{l}\text { Evalu } \\
\text { asi } \\
\text { (ei) }\end{array}$ & \\
\hline $\begin{array}{l}\text { Warna } \\
\text { Daging } \\
\text { Sapi }\end{array}$ & 3,933 & 4,160 & 16,36 \\
\hline $\begin{array}{l}\text { Kandunga } \\
\text { n Lemak } \\
\text { Bagian }\end{array}$ & 2,387 & 2,093 & 4,996 \\
\hline $\begin{array}{l}\text { Daging } \\
\text { Sapi }\end{array}$ & 3,947 & 4,293 & 16,94 \\
\hline & mlah & & 38,303 \\
\hline
\end{tabular}

Sumber: data primer diolah (2015)

Pada analisis evaluation (evaluasi) atribut yang paling dipertimbangkan oleh konsumen dalam pembelian daging sapi adalah "bagian daging sapi" dengan nilai 4,293. Artinya knsumen merasa bahwa penilaian terhadap bagian daging sapi adalah hal yang paling utama dalam membentuk sikap terhadap pembelian daging sapi.

Tabel 7 juga menjelaskan tentang sikap konsumen terhadap atribut daging sapi yang dipertimbangkan dalam keputusan pembelian daging sapi berturut-turut dari yang paling tinggi sampai yang paling rendah adalah Bagian Daging Sapi dengan nilai sebesar 16,944. Artinya atribut "bagian daging sapi" merupakan atribut yang paling dipertimbangkan konsumen di Kabupaten Jember. Untuk mengetahui sikap konsumen secara keseluruhan termasuk dalam kategori penilaian yang mana, maka harus dihitung terlebih dahulu skala intervalnya. Berdasarkan skala interval sikap diketahui bahwa jumlah skor sikap dengan nilai 38,303 ini termasuk dalam kategori cukup baik $(31,80-46,15)$. Atribut bagian daging sapi menempati urutan tertinggi baik pada tingkat kepercayaan maupun evaluasi, sedangkan secara keseluruhan sikap konsumen terhadap daging sapi ini adalah cukup baik. Artinya "bagian daging sapi" merupakan nilai sikap tertinggi pada kedua atribut yang lainnya.

Nilai terhadap "Bagian Daging Sapi" menunjukkan bahwa konsumen rumah tangga mengkonsumsi daging sapi melihat "Bagian Daging Sapi" sebagai pilihan utama 
untuk dikonsumsi. Bagian daging sapi sangat banyak manfaat dan macamnya. Selain memiliki manfaat dan macamnya, bagian daging sapi lebih dinilai bervariasi ketimbang warna daging dan kandungan lemak pada daging sapi, sehingga konsumen melihatnya tidak dari satu sisi warna dan kandungan lemak, akan tetapi bagian daging sapi mana yang mereka butuhkan untuk dikonsumsi.

Adapun beberapa bagian daging sapi yang banyak dukonsumsi oleh konsumen diantaranya: tetelan (rawonan), tulangan, jeroan (hati, paru, usus), iga, dan buntut. Konsumsi bagian daging sapi yang paling banyak dibeli yaitu tetelan (rawonan), karena dianggap banyak mengandung gizi, khususnya protein pada bagian daging sapi ini. Konsumsi jeroan juga menjadi bagian daging sapi yang banyak dikonsumsi, dikalangan masyarakat luas, jeroan biasanya disajikan dalam makanan olahan baru seperti bakso dan soto. Tulangan, iga dan buntut menjadi bagian daging sapi yang dikonsumsi dengan harga yang lebih mahal dalam bentuk olahan baru.

Variabel "Warna Daging Sapi" menunjukkan konsumen rumah tangga tidak terlalu mempertimbangkan warna untuk dikonsumsi. Beberapa konsumen menilai kualitas daging sapi yang bagus itu dilihat dari warnanya yang segar, akan tetapi di jaman sekarang ini banyak pedagang dan konsumen kurang memahami akan warna daging sapi yang sehat. Jika ingin mendapatkan kualitas daging sapi yang baik sebaiknya daging sapi yang masih segar dan belum berumur satu minggu, warna daging sapi tersebut terlihat merah cerah dan masih segar, agar ingin terlihat segar biasanya dimasukkan ke dalam lemari es atau didiamkan pada tempat yang suhunya dibawah $0^{\circ}$ C. Biasanya pedagang yang melakukan hal yang kurang baik melakukan suatu cara pada daging yang sudah berumur lama agar terlihat segar, dengan memberikan campuran pewarna kimia. Selain itu harganya cenderung murah dibandingkan harga daging sapi yang masih segar. Warna daging sapi yang dianggap tidak segar biasanya dikonsumsi dengan cara direbus sampai lunak agar bakteri yang melekat mati dan aman untuk dikonsumsi.
Variabel "Kandungan Lemak" merupakan penilaian yang nilainya paling rendah. Konsumen kurang begitu menikmati olahan kandungan lemak pada daging sapi. Lemak pada daging sapi memiliki bau yang berbeda dengan daging kambing, sehingga masih dipertimbangkan untuk dikonsumsi lebih daripada lemak pada daging kambing. Kandungan lemak pada daging sapi biasanya sangat rawan bagi konsumen yang umurnya berada di atas 40 tahun

\section{KESIMPULAN}

Kesimpulan yang dapat diambil dari penelitian ini: (1) tingkat pendapatan, harga daging ayam dan populasi sapi secara bersama-sama berpengaruh terhadap permintaan daging sapi di Kabupaten Jember, sedangkan secara individual faktorfaktor yang tidak berpengaruh yaitu, faktor jumlah penduduk dan faktor produksi daging sapi. (2) Faktor-faktor yang mempengaruhi perilaku konsumen rumah tangga untuk mengkonsumsi daging sapi di Kabupaten Jember digolongkan menjadi 6 faktor, Faktor Budaya (kebudayaan, sub-budaya dan kepercayaan). Faktor Karakter Eksternal Konsumen (pekerjaan, keadaan ekonomi, kelas sosial dan umur). Faktor Sosial (keluarga, referensi, peran dan proses belajar). Faktor Persepsi. Faktor Pribadi (kepribadian dan gaya hidup). Faktor Motivasi. (3) Preferensi konsumen rumah tangga terhadap daging sapi yang paling dipilih di Kabupaten Jember berdasarkan sikap pembelian bagian daging sapi $(16,944 \%)$, warna daging sapi $(16,363 \%)$ dan kandungan lemak daging sapi (4,966\%).

\section{DAFTAR PUSTAKA}

Aziz, Muhammad Abdul. 2009. Analisis Faktor - Faktor yang Mempengaruhi Konsumsi Masyarakat di Provinsi Jawa Tengah Tahun 2003 - 2007. Skripsi Fakultas Ekonomi Jurusan Ekonomi Pembangunan Universitas Sebelas Maret.

Dirjen Peternakan. 2009. Konsumsi Daging Di Indonesia. Jakarta : Direktorat Jenderal Peteranakan Departemen Pertanian. 
Engel, J.L, Roger D. Blackwell and Paul W. Minlard. 1994. Perilaku Konsumen. Alih Bahasa F.X. Budianto. Jakarta: Binarupa Aksara.

Hair, J.F., et al. 1992. Multivariate Data Analysis. 3rd edition. Prentice. New Jersey: Hall International, Inc.

Hasan, I. M. 2005. Pokok-pokok Materi Statistik 2. Jakarta: Bumi Aksara.

Sajogyo, T. 1997. Garis Kemiskinan dan Kebutuhan Minimum Pangan. Bogor: LPSB-IPB.

Santoso, dan Fandy. 2004. Riset Pemasaran : Konsep dan Aplikasi dengan SPSS. Jakarta: PT. Elex Media Komputindo.
Schiffman, Leon dan Leslie Lazar Kanuk. 2008. Consumer Behavior $7^{\text {th }}$ Edition (Perilaku Konsumen). Jakarta: PT. Indeks.

Sugiyono. 2011. Metodologi Penelitian Kuntitatif Kualitatif dan $R \& D$. Bandung: Alfabeta.

Sukirno, Sadono. 2002. Ekonomi Mikro. Jakarta: Rajawali Press.

Sunarto. 2006. Perilaku Konsumen. Yogyakarta: Penerbit Amus.

Umiyasih. 2004. Usaha Sapi Potong di Indonesia. Yogyakarta: Liberty.

Wibisono, D. 2003. Riset Bisnis Panduan bagi Praktisi dan Akademis. Jakarta: Gramedia Pustaka Utama. 